\title{
Chemical characteristics of aerosols in MABL of Bay of Bengal and Arabian Sea during spring inter-monsoon: A comparative study
}

\author{
Ashwini Kumar, A K Sudheer and M M Sarin* \\ Physical Research Laboratory, Navrangpura, Ahmedabad 380 009, India. \\ *e-mail:sarin@prl.res.in
}

The chemical composition of aerosols in the Marine Atmospheric Boundary Layer (MABL) of Bay of Bengal (BoB) and Arabian Sea (AS) has been studied during the spring and inter-monsoon (March-May 2006) based on the analysis of water soluble constituents $\left(\mathrm{Na}^{+}, \mathrm{NH}_{4}^{+}, \mathrm{K}^{+}, \mathrm{Mg}^{2+}\right.$, $\mathrm{Ca}^{2+}, \mathrm{Cl}^{-}, \mathrm{NO}_{3}^{-}$and $\mathrm{SO}_{4}^{2-}$ ), crustal elements (Al, Fe, and $\mathrm{Ca}$ ) and carbonaceous species (EC, OC). The total suspended particulates (TSP) ranged from 5.2 to $46.6 \mu \mathrm{g} \mathrm{m}^{-3}$ and 8.2 to $46.9 \mu \mathrm{g} \mathrm{m}^{-3}$ during the sampling transects in the $\mathrm{BoB}$ and AS respectively. The water-soluble species, on average, accounted for $44 \%$ and $33 \%$ of TSP over BoB and AS respectively, with dominant contribution of $\mathrm{SO}_{4}^{2-}$ over both the oceanic regions. However, distinct differences with respect to elevated abundances of $\mathrm{NH}_{4}^{+}$in the MABL of $\mathrm{BoB}$ and that of $\mathrm{Na}^{+}$and $\mathrm{Ca}^{2+}$ in $\mathrm{AS}$ are clearly evident. The non-sea-salt component of $\mathrm{SO}_{4}^{2-}$ ranging from 82 to $98 \%$ over $\mathrm{BoB}$ and 35 to $98 \%$ over AS; together with nss- $\mathrm{Ca}^{2+} / \mathrm{nss}^{-} \mathrm{SO}_{4}^{2-}$ equivalent ratios 0.12 to 0.5 and 0.2 to 1.16 , respectively, provide evidence for the predominance of anthropogenic constituents and chemical transformation processes occurring within MABL. The concentrations of $\mathrm{OC}$ and $\mathrm{EC}$ average around 1.9 and $0.4 \mu \mathrm{g} \mathrm{m}^{-3}$ in BoB and exhibit a decreasing trend from north to south; however, abundance of these carbonaceous species are not significantly pronounced over AS. The abundance of Al, used as a proxy for mineral aerosols, varied from 0.2 to $1.9 \mu \mathrm{g} \mathrm{m}^{-3}$ over $\mathrm{BoB}$ and $\mathrm{AS}$, with a distinctly different spatial pattern - decreasing north to south in BoB in contrast to an increasing pattern in the Arabian Sea.

\section{Introduction}

In the present-day scenario of growing anthropogenic activities, it is undisputedly recognized that atmospheric aerosols are one of the important driving parameters to regulate the chemical composition of the earth's atmosphere. Their significant impact on atmosphere is of utmost interest as they participate in various physico-chemical processes, scatter and absorb incoming solar radiation, provide active sites for the uptake of several chemical species and trace gases and act as cloud condensation nuclei (CCN) in modifying the cloud properties (Twomey 1977; Charlson et al 1992; Ramanathan et al 2001a, 2001b). The continen- tally derived aerosols from natural (mineral dust) and anthropogenic $\left(\mathrm{SO}_{4}^{2-}, \mathrm{NO}_{3}^{-}\right)$sources, when transported to the remote marine environment, can perturb the marine ecosystem in a changing climate scenario (Prospero et al 1981; Martin et al 1989; Duce et al 1991; Arimoto et al 2001; Jickells et al 2005). The atmospheric aerosols exhibit a significant spatial and temporal variation owing to its short lifetime, which induces a large uncertainty in radiative forcing calculations. The systematic data on chemical composition of aerosols from oceanic regions is of great relevance in the present context in order to place better constraints on the input parameters in chemical transport models.

Keywords. Aerosol chemistry; water-soluble ions; carbonaceous species; mineral dust. 
ICARB Sampling Track

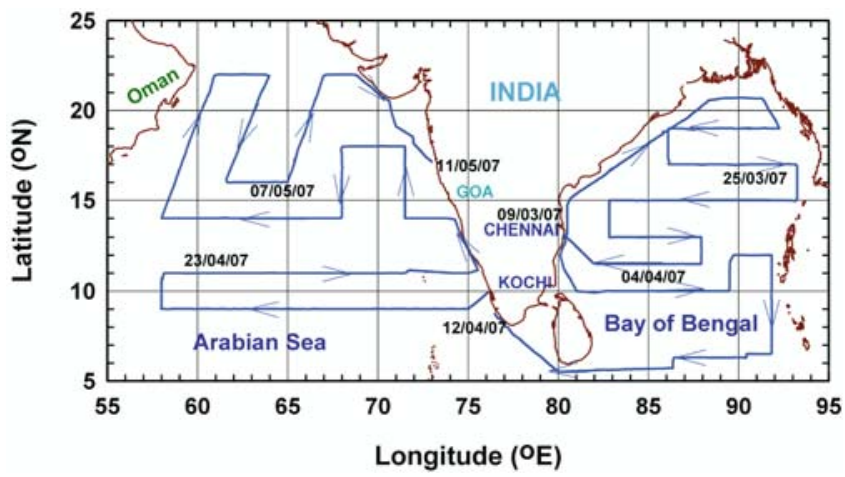

Figure 1. The cruise transects carried out in the Bay of Bengal and Arabian Sea for collection of bulk-aerosol samples during spring inter-monsoon (March-May 2006).

With this rationale, the ICARB (Integrated Campaign for Aerosols, gases and Radiation Budget) field experiment on an Indian scene was primarily designed to study several parameters of atmospheric aerosols and trace gases. The specific scientific objective of this campaign-based programme was to quantify the impact of long-range transport of aerosols and trace gases from different source regions of India, south China, and east Asia to the Bay of Bengal (BoB); and that from northwestern India, west Asia and Africa to the Arabian Sea (AS). In this paper we report on the comparative chemical composition of aerosols from the two (BoB and $\mathrm{AS}$ ) oceanic regions vis-à-vis continental outflow of mineral dust and anthropogenic species from the Indian subcontinent.

\section{Methodology}

\subsection{Cruise track and meteorological conditions}

Figure 1 shows the cruise track (cruise No. SK 223A and 223B) undertaken onboard ORV Sagar Kanya, during 18 March to 12 April, in the Bay of Bengal; and 18 April to 11 May 2006 in the Arabian Sea. Several transects were made between $5.6^{\circ} \mathrm{N}$ to $20.5^{\circ} \mathrm{N}$ and $80.4^{\circ} \mathrm{E}$ to $93.4^{\circ} \mathrm{E}$ in $\mathrm{BoB}$ and $9^{\circ} \mathrm{N}$ to $22^{\circ} \mathrm{N}$ and $77.3^{\circ} \mathrm{E}$ to $58^{\circ} \mathrm{E}$ covering almost an entire area of the Arabian Sea. The dots along the cruise track show the position of the ship at 05:30 UTC on each day. The prevailing winds were north-westerly during the SK 223A leg in $\mathrm{BoB}$ and remained same for the few early days of SK 223B; however changed to south-westerly towards the end of the cruise in Arabian Sea. The relative humidity varied from 50 to $100 \%$, with a mean of about $80 \%$ during the entire campaign period. The prevailing winds, corrected for the ship's motion, were found to vary between 0.5 and
$13.5 \mathrm{~m} / \mathrm{s}$, whereas surface-level pressure variations were recorded in the range of 1002 to $1016 \mathrm{mb}$. The winds were generally strong $(\sim 13 \mathrm{~m} / \mathrm{s})$ during the sampling transect in the central Arabian Sea and relatively moderate $(\sim 9 \mathrm{~m} / \mathrm{s})$ in the northern Arabian Sea.

\subsection{Aerosol sampling and analysis}

Bulk-aerosol samples were collected on PALLFLEX ${ }^{\mathrm{TM}}$ tissuquartz filters $\left(20 \times 25 \mathrm{~cm}^{2}\right)$ by operating a high-volume sampler at a flow rate of about $1.5 \mathrm{~m}^{3} \mathrm{~min}^{-1}$. The sampler was set-up on the upper deck, $16 \mathrm{~m}$ asl, in front of the ship's navigation room. A total of 23 and 19 samples were collected over BoB and AS respectively. Each sample was collected by running the sampler for an extended time-period, ranging from 18 to $24 \mathrm{~h}$, whenever the ship was cruising at a speed of $\sim 10$ knots/h or above; thus avoiding contamination from the ship's exhaust. In the laboratory, Total Suspended Particulate (TSP) mass concentrations were assessed gravimetrically by weighing the full filters before and after sampling. Prior to their weighing, all filters were equilibrated at a relative humidity of $50 \pm 5 \%$ and temperature of $22 \pm 1{ }^{\circ} \mathrm{C}$ for 5-6h. Subsequently sample filters were subjected to chemical analysis of water-soluble constituents $\left(\mathrm{Na}^{+}, \mathrm{NH}_{4}^{+}, \mathrm{K}^{+}, \mathrm{Mg}^{2+}, \mathrm{Ca}^{2+}, \mathrm{Cl}^{-}, \mathrm{NO}_{3}^{-}\right.$ and $\mathrm{SO}_{4}^{2-}$ ), crustal elements (Fe, $\mathrm{Al}$ and $\mathrm{Ca}$ ) and carbonaceous species. For water-soluble components one-eighth of the filter was soaked in Milli-Q water (resistivity $=18.2 \mathrm{M} \Omega \mathrm{cm}$ ) for $10-12 \mathrm{~h}$ followed by ultrasonication; repeated leaching with water were combined and made to a known volume. The anions $\left(\mathrm{Cl}^{-}, \mathrm{NO}_{3}^{-}\right.$and $\left.\mathrm{SO}_{4}^{2-}\right)$ and cations $\left(\mathrm{Na}^{+}, \mathrm{NH}_{4}^{+}, \mathrm{K}^{+}, \mathrm{Mg}^{2+}\right.$, and $\left.\mathrm{Ca}^{2+}\right)$ were analyzed on Ion Chromatograph with suppressed conductivity detector. Based on blank concentrations and the average volume of air filtered $\left(\sim 2000 \mathrm{~m}^{3}\right)$, the detection limits for the water-soluble ionic species in aerosols were ascertained $(18,18,20,18,25,6$, 10 and $30 \mathrm{ng} \mathrm{m}{ }^{-3}$ for $\mathrm{Na}^{+}, \mathrm{NH}_{4}^{+}, \mathrm{K}^{+}, \mathrm{Mg}^{2+}, \mathrm{Ca}^{2+}$, $\mathrm{Cl}^{-}, \mathrm{NO}_{3}^{-}$and $\mathrm{SO}_{4}^{2-}$ respectively).

The crustal elements ( $\mathrm{Al}, \mathrm{Fe}$ and $\mathrm{Ca}$ ) were analyzed by inductively coupled plasma-atomic emission spectroscopy (ICP-AES) on a separate one-eighth portion of the filter, digested using $0.5 \mathrm{ml} \mathrm{HF}$ and $3 \mathrm{ml} \mathrm{HNO}_{3}$ in a microwave oven and total volume increased to $25 \mathrm{ml}$ with Milli-Q water. Prior to acid digestion, filter was combusted in an oven at $400^{\circ} \mathrm{C}$ for three hours to oxidize the organic coating (if any) on the particulate matter. A multielement commercial standard $\left(1000 \mu \mathrm{g} \mathrm{m}^{-1}\right.$ w.r.t. 23 elements), after suitable dilution, was used for preparation of analytical calibration curve. Based on the repeat analysis of a number of 
samples and standards, reproducibility in the analytical data for crustal elements was within $10 \%$. The concentrations of elemental carbon (EC) and organic carbon (OC) were determined by a thermal/optical analyzer (Birch and Cary 1996). Details of analytical protocol on EC-OC measurements used in our lab have been described in a recent article by Rengarajan et al (2007). The detection limit for $\mathrm{OC}$ and $\mathrm{EC}$ was 0.1 and $0.05 \mu \mathrm{g} \mathrm{m}^{-3}$ respectively; using $3 \sigma$ value of total procedural blank concentration of the filter and volume of air sampled $\left(\sim 2000 \mathrm{~m}^{3}\right)$.

\section{Results and discussion}

\subsection{Air-mass back trajectory analysis}

Air-mass back trajectories (AMBT) are one of the diagnostic parameters to infer the source region from where the aerosol mass has originated and the subsequent transport to the sampling location. The 7-day back trajectory analysis was made for the cruise duration, using the Hysplit- 4 model and FNL-meteorological dataset at 50,100, $500 \mathrm{~m}$ altitude, in order to track the origin of air parcels at various locations. During the initial phase of the cruise SK 223A, in BoB, the polluted air parcel from north-eastern India dominates the aerosols transport. During later part of the cruise covering southern transects in the $\mathrm{BoB}$, winds originated within the oceanic region for a few days (28 March to 6 April); otherwise, the wind pattern remained more or less same (north-westerly) carrying the continental outflow to the marine environment.

In the Arabian Sea, the transition of wind regimes was discernible based on AMBT analysis. During initial phase of the cruise in the AS, AMBT originated from north-western part of Arabian Sea (off the coast of Oman). With the progressive cruise transects in the northern region of AS, the AMBTs show south-westerly winds originating within the MABL. The northward progression of ITCZ - a characteristic feature for the onset of SW-monsoon winds over the Arabian Sea was also observable. The ITCZ acts as a barrier to restrict the transport of continental (anthropogenic and natural) derived constituents to the south of ITCZ. During the winter-monsoon, a sharp gradient occurs across the ITCZ with concentration of nss- $\mathrm{SO}_{4}^{2-}, \mathrm{NH}_{4}^{+}$, and nss- $\mathrm{K}^{+}$decreasing by an order of magnitude on the southern side of ITCZ (Norman et al 2003). This suggests that the entrainment of continental aerosols (transported during NE/NW-winds), north of ITCZ, will impact the abundances of chemical species in the central and northern Arabian Sea.

\subsection{Total suspended particulate (TSP) matter}

The abundance of TSP in the MABL of BoB and AS was found to vary from 5.2 to 46.2 and 8.2 to $46.9 \mu \mathrm{g} \mathrm{m}^{-3}$ respectively (table 1 ). Typical high values of TSP in $\mathrm{BoB}$ are observed at sampling locations along the south-eastern coast of India. Overall, a decreasing trend in TSP mass concentration was seen from north to south BoB; suggesting diminishing impact of atmospheric transport from continental sources. The AMBTs also confirm that air-parcels in the BoB have mainly originated from the Indian urban region. In contrast, high TSP abundances are observed in southern transect over AS, although the highest TSP $\left(46.9 \mu \mathrm{g} \mathrm{m}^{-3}\right)$ was recorded on 8 May, in the northernmost transect of Arabian Sea. Transport from arid and semiarid regions of Oman coast to southern Arabian Sea, and airmasses originating within the marine environment affecting the aerosol characteristic in northern Arabian Sea are also supported by AMBT analysis.

\subsection{Water-soluble ions}

Water-soluble inorganic species ranged from 30 to $72 \%$ (Av: 44\%; sd: $12 \%$ ) and 22 to $70 \%$ (Av: $33 \%$; sd: $12 \%$ ) of TSP in BoB and AS respectively. A comparison of charge balance between total cations $\left(\Sigma^{+}\right)$and total anions $\left(\Sigma^{-}\right)$in the watersoluble fraction of aerosols over the two regions is shown in figure 2 . The $\Sigma^{+} / \Sigma^{-}$ratio varied between 0.89 and 1.30 (Av: 1.11; sd: 0.08) and 0.80 and 1.20 (Av: 1.06; sd: 0.09) over BoB and AS respectively. A relatively larger deviation of data points from 1:1 line is observable for water-soluble constituents in the MABL of BoB compared to the AS. This is attributed to the lack of bicarbonate measurement and hence resulting in cation excess. Rastogi et al (2005), had made direct measurements of bicarbonate ion in ambient aerosols over semi-arid regions and significant cation excess was reported during winter months (November-February). The dominant contribution from regional dust sources to the overall chemical composition of aerosols in the MABL of seas around India requires independent measurement of bicarbonate ion for the anion balance. Few earlier studies over the Indian region (Kulshrestha et al 1998; Momin et al 1999; Venkatraman et al 2002) have also demonstrated cation excess in the ion-balance.

The average aerosol composition of water-soluble species, in the MABL of $\mathrm{BoB}$ and $\mathrm{AS}$, during the sampling period representing inter-monsoon season, is shown in figure 3; with dominant contribution of sulphate over both the regions. On average, contribution of $\mathrm{SO}_{4}^{2-}$ to TSP was 68 and 
Table 1. Average concentration of chemical species in bulk-aerosols from MABL over Bay of Bengal (BoB) and Arabian Sea (AS), along with minimum and maximum values (all units in $\mu \mathrm{g} \mathrm{m}^{-3}$ ) and standard deviation of the data. Number of samples in $B o B=23 ; A S=19$.

\begin{tabular}{|c|c|c|c|c|c|c|c|c|}
\hline \multirow[b]{2}{*}{ Component } & \multicolumn{5}{|c|}{ Bay of Bengal, $n=23$} & \multicolumn{3}{|c|}{ Arabian Sea ${ }^{\$}, n=19$} \\
\hline & Mean & Std. dev. & Min & Max & Mean & Std. dev. & Min & Max \\
\hline TSP & 22.5 & 13.0 & 5.2 & 46.6 & 24.7 & 10.4 & 8.2 & 46.9 \\
\hline Water-soluble & 8.9 & 3.7 & 3.8 & 15.7 & 10.7 & 5.9 & 2.7 & 23.7 \\
\hline $\mathrm{nss}-\mathrm{SO}_{4}^{2-}$ & 5.8 & 2.4 & 2.5 & 10.3 & 2.9 & 1.2 & 1.3 & 5.7 \\
\hline $\mathrm{Al}$ & 0.92 & 0.54 & 0.19 & 1.89 & 0.85 & 0.47 & 0.21 & 1.89 \\
\hline $\mathrm{Ca}$ & 0.73 & 0.36 & 0.20 & 1.42 & 0.90 & 0.60 & 0.13 & 2.48 \\
\hline $\mathrm{Fe}$ & 0.59 & 0.31 & 0.15 & 1.22 & 0.44 & 0.27 & 0.09 & 1.01 \\
\hline $\mathrm{Na}^{+}$ & 0.86 & 0.62 & 0.16 & 1.90 & 1.92 & 2.43 & 0.22 & 10.27 \\
\hline $\mathrm{NH}_{4}^{+}$ & 0.90 & 0.63 & 0.01 & 2.29 & BDL & BDL & BDL & BDL \\
\hline $\mathrm{K}^{+}$ & 0.24 & 0.11 & 0.08 & 0.43 & 0.12 & 0.08 & 0.04 & 0.42 \\
\hline $\mathrm{Mg}^{2+}$ & 0.16 & 0.08 & 0.05 & 0.30 & 0.20 & 0.26 & 0.04 & 1.13 \\
\hline $\mathrm{Ca}^{2+}$ & 0.68 & 0.35 & 0.17 & 1.42 & 0.85 & 0.56 & 0.12 & 2.24 \\
\hline $\mathrm{Cl}^{-}$ & 0.013 & 0.010 & $\mathrm{BDL}^{*}$ & 0.042 & 2.16 & 3.88 & $\mathrm{BDL}$ & 15.26 \\
\hline $\mathrm{NO}_{3}^{-}$ & 0.075 & 0.089 & BDL & 0.35 & 0.40 & 0.40 & BDL & 1.34 \\
\hline $\mathrm{OC}$ & 1.88 & 1.59 & 0.26 & 5.46 & 0.21 & 0.15 & BDL & 0.68 \\
\hline $\mathrm{EC}$ & 0.39 & 0.16 & 0.12 & 0.66 & 0.08 & 0.03 & $\mathrm{BDL}$ & 0.20 \\
\hline POM & 3.95 & 3.33 & 0.55 & 11.47 & 0.44 & 0.32 & 0.21 & 1.42 \\
\hline nss-SO ${ }_{4}^{2-}(\%)$ & 28.7 & 8.9 & 19.0 & 50.2 & 12.7 & 4.3 & 3.0 & 20.7 \\
\hline Dust (\%) & 49.2 & 9.3 & 34.8 & 67.7 & 44.0 & 15.0 & 13.0 & 77.7 \\
\hline Sea-salts (\%) & 6.1 & 4.5 & 1.5 & 17.8 & 16.2 & 16.4 & 1.9 & 64.7 \\
\hline POM (\%) & 14.7 & 5.0 & 8.5 & 24.8 & 1.8 & 1.0 & 0.7 & 5.1 \\
\hline
\end{tabular}

${ }^{*} \mathrm{BDL}=$ Below Detection Limit.

${ }^{\$}$ Kumar et al (2008).

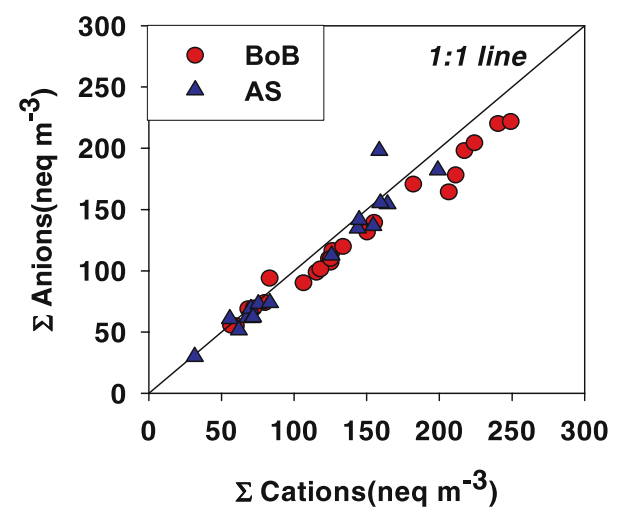

Figure 2. The charge balance between $\Sigma$ cations and $\Sigma$ anions over both oceanic regions for the water-soluble species in the aerosol samples. Anion deficiency is mostly observed in the Bay of Bengal which can be attributed to the presence of organic acids or $\mathrm{HCO}_{3}^{-}$ions (not measured) in the water extracts.

$47 \%$ over $\mathrm{BoB}$ and $\mathrm{AS}$, respectively. The particulate $\mathrm{SO}_{4}^{2-}$ is formed by oxidation of $\mathrm{SO}_{2}$, with dominant contribution derived from fossil fuel combustion and relatively weaker source from biogenic gases such as dimethyl sulphide (in marine region). In addition, sea-salt also contributes to the $\mathrm{SO}_{4}^{2-}$ concentration. In the present study,
$\mathrm{Na}$ has been used as a reference for sea-salts. The $\mathrm{Mg}^{2+} / \mathrm{Na}^{+}$ratios (in equivalent units) in the Arabian Sea are quite similar to their abundances in sea-water $\left(\mathrm{Mg}^{2+} / \mathrm{Na}^{+}=0.22\right.$ in seawater). But consistently higher $\mathrm{Mg}^{2+} / \mathrm{Na}^{+}$ratio in the MABL of $\mathrm{BoB}$ could be attributed to the transport of alkaline fly ash from coal-fired power plants. The sea-salt corrected component of $\mathrm{SO}_{4}^{2-}$ is estimated as nss- $\mathrm{SO}_{4}^{2-}=\left[\mathrm{SO}_{4}^{2-}\right]_{\text {Total }}-$ $\left[\mathrm{Na}^{+}\right] * 0.2516$. The nss-SO ${ }_{4}^{2-}$ abundance varied from 2.5 to $10.2 \mu \mathrm{g} \mathrm{m}^{-3}$ (Av: $5.7 \mu \mathrm{g} \mathrm{m}^{-3}$; constituting $92 \%$ of total $\mathrm{SO}_{4}^{2-}$ ) in the MABL of $\mathrm{BoB}$ and 1.3 to $5.7 \mu \mathrm{g} \mathrm{m}^{-3}$ (Av: $2.9 \mu \mathrm{g} \mathrm{m}^{-3}$; constituting $86 \%$ of total $\mathrm{SO}_{4}^{2-}$ ) over AS respectively. The relatively higher abundance of nss- $\mathrm{SO}_{4}^{2-}$ over $\mathrm{BoB}$ suggests greater influence of anthropogenic sources to aerosol loading over BoB. A scatter plot between $\mathrm{nss}^{-\mathrm{Ca}^{2+}}$ and nss-SO ${ }_{4}^{2-}$ (in equivalent units) is shown in figure 4 , showing significant correlation, $r^{2}=0.67$ and 0.62 with slopes $=0.73$ and 2.23 for $\mathrm{AS}$ and $\mathrm{BoB}$ respectively. These results together with nss- $\mathrm{Ca}^{2+}$ contributing 95 and $89 \%$ to the total $\mathrm{Ca}^{2+}$ over BoB and AS, respectively, suggest their long-range transport from continental sources.

Another notable feature of the water-soluble species over the two oceanic regions relate to 


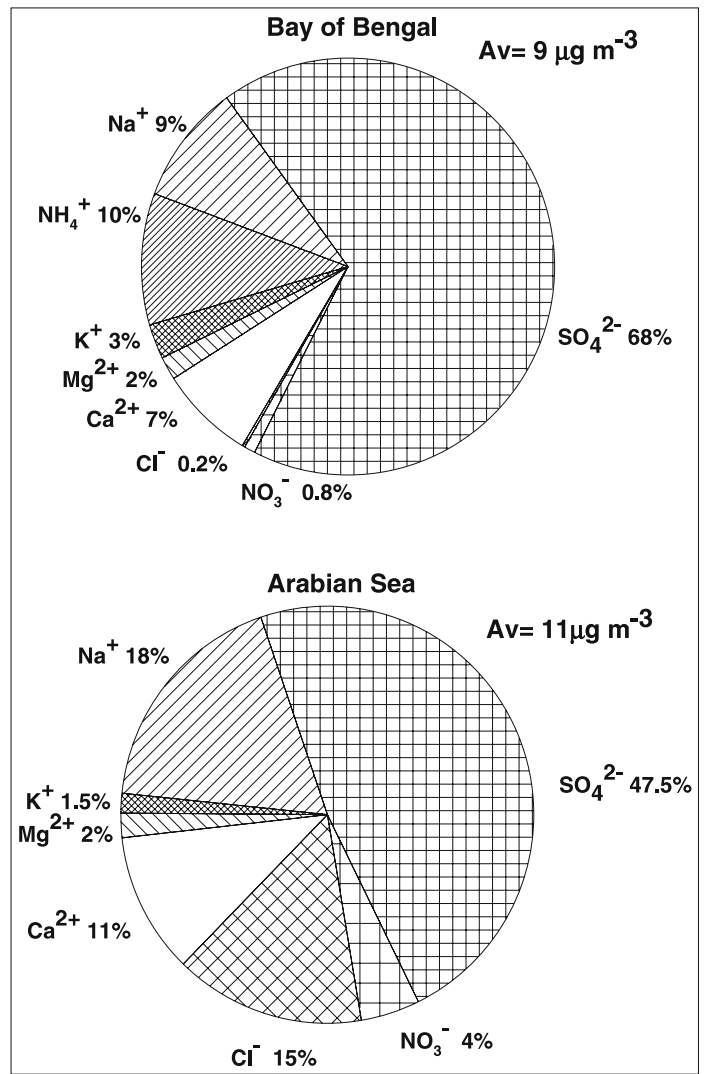

Figure 3. Average water-soluble composition of aerosols over Bay of Bengal and Arabian Sea, reflecting dominance of $\mathrm{SO}_{4}^{2-}$.

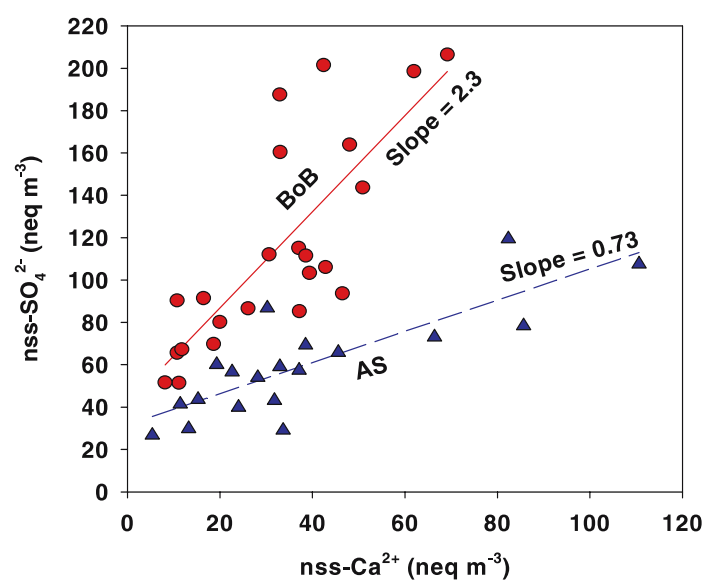

Figure 4. The linear regression analysis among nss-Ca ${ }^{2+}$ and nss- $\mathrm{SO}_{4}^{2-}$ abundances exhibits different slopes for the data from two oceanic regions. Relatively higher slope for $\mathrm{BoB}$ indicates the dominance of anthropogenic sources over this oceanic region.

$\mathrm{Cl}^{-}$-deficit with respect to the expected abundance of $\mathrm{Cl}^{-}$based on $\mathrm{Na}^{+}$and $\mathrm{Cl}^{-}$ratio in seasalts. Chloride-deficit is the process by which acidic species mainly nitrate, sulphate and some organic acids, react with $\mathrm{NaCl}$ in sea-salt particles and

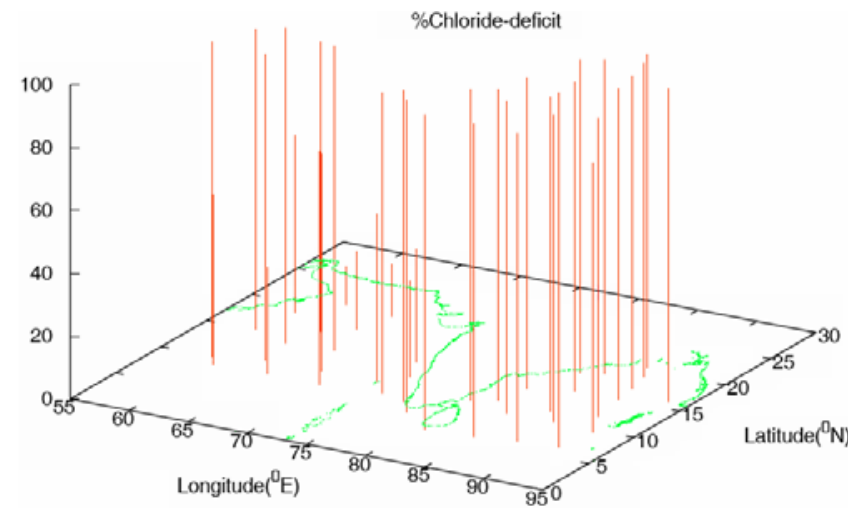

Figure 5. The spatial and temporal variability in the $\mathrm{Cl}^{-}$-deficit (\%) observed over Bay of Bengal (19 March to 12 April) and Arabian Sea (18 April to 8 May).

replace chloride in the form of $\mathrm{HCl}$ gas. The chloride deficit has been calculated as follows:

$$
\begin{aligned}
& \mathrm{Cl}^{-} \text {deficit (\%) } \\
& \quad=\left[\left(\mathrm{Na}^{+} \times 1.16\right)-\mathrm{Cl}_{\mathrm{m}}^{-}\right] \times 100 /\left(\mathrm{Na}^{+} \times 1.16\right),
\end{aligned}
$$

where $\left(\mathrm{Na}^{+} \times 1.16\right)$ is expected $\mathrm{Cl}^{-}$concentration from sea-salts, in absence of any loss of $\mathrm{Cl}^{-}$and all $\mathrm{Na}^{+}$in ambient aerosols is of sea-salt origin, $\mathrm{Cl}_{\mathrm{m}}^{-}$is chloride measured in the sample. A large $\mathrm{Cl}^{-}$-deficit was observed in the MABL over BoB (86 to almost 100\%; Av: 98\%) compared to AS (12 to $100 \%$; Av: $62.7 \%$ ). The spatial variability in the $\mathrm{Cl}^{-}$-deficit in the two oceanic regions is shown in figure 5. The magnitude of $\mathrm{Cl}^{-}$-deficit was found to decrease with increasing particle size (Kerminen et al 1998). The increased $\mathrm{Cl}^{-}$-deficit over $\mathrm{BoB}$ than in the AS indicates the dominance of finer aerosols (anthropogenic input); an observation also supported by relatively high abundance of nss- $\mathrm{SO}_{4}^{2-}$.

The concentration of $\mathrm{NO}_{3}^{-}$is insignificant over both regions representing background concentration levels over these oceanic regions, while relatively higher abundance of $\mathrm{K}^{+}$over $\mathrm{BoB}$ indicates the biomass burning emissions from central/north-eastern part of India and their subsequent transport to northern BoB. However, it is noteworthy that the $\mathrm{NH}_{4}^{+}$contribution to the water-soluble species is significant over $\mathrm{BoB}$, and is nearly absent over AS. Particulate $\mathrm{NH}_{4}^{+}$is formed by reaction of ammonia gas with acidic species and $\mathrm{NaCl}$ present in sea-salts. However, the formation of ammonium nitrate and ammonium chloride by these interactions are thermodynamically unstable and can cause a negative artifact for particulate $\mathrm{NH}_{4}^{+}$(Witz et al 1990). Over BoB, one of the main 


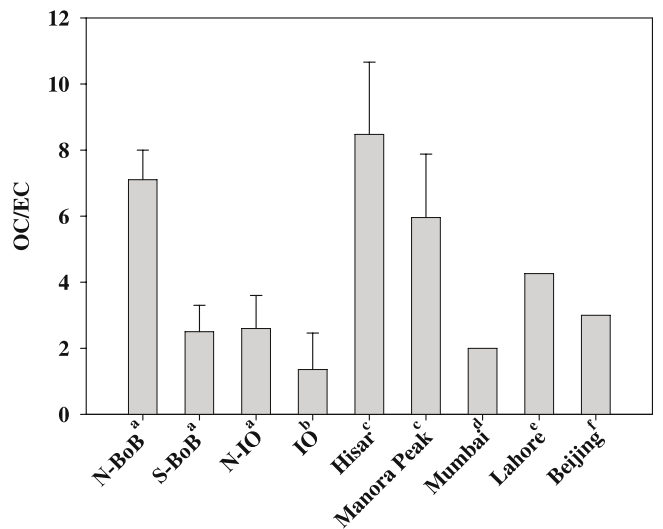

${ }^{\mathrm{a}}$ This study $\quad$ Rengarajan et al (2007) $\quad$ 'Smith et al (1996)

${ }^{\text {b } M a y o l-B r a c e r o ~ e t ~ a l ~(2002) ~}{ }^{d}$ Venkataraman et al (2002) $\quad$ 'Duan et al (2005)

Figure 6. Comparison of OC/EC ratio from adjacent urban and remote locations.

neutralizing species of acidic $\mathrm{SO}_{4}^{2-}$ component is $\mathrm{NH}_{4}^{+}$, but over the AS, the major neutralizing agent is alkaline dust.

\subsection{Carbonaceous aerosols}

The abundance of carbonaceous species in the MABL of Bay of Bengal shows a large spatial variability; organic carbon (OC) varied as: $0.3-$ $5.5 \mu \mathrm{g} \mathrm{m}^{-3}$ (Av: 1.9; sd: 1.6) and elemental carbon (EC): $0.12-0.7 \mu \mathrm{g} \mathrm{m}^{-3}$ (Av: 0.4; sd: 0.2) (table 1); with a conspicuous decreasing trend from north to south BoB. In contrast, the contribution of EC and OC to the TSP is insignificant along the entire cruise track in the Arabian Sea. The abundance of EC and OC varied from $<0.05$ to $0.2 \mu \mathrm{g} \mathrm{m}^{-3}$ (Av: $0.08 \mu \mathrm{g} \mathrm{m}^{-3}$ ) and $<0.1$ to $0.68 \mu \mathrm{g} \mathrm{m}^{-3}$ (Av: $\left.0.21 \mu \mathrm{g} \mathrm{m}^{-3}\right)$ respectively. Using OC concentration, mass of particulate organic matter (POM) has been estimated over both regions (Turpin and Lim 2001; Quinn et al 2002; Kumar et al 2008). It is evident from earlier discussions that the relative dominance of anthropogenic sources over $\mathrm{BoB}$ is also reflected in the abundance of carbonaceous species.

EC is considered to be primary aerosols in contrast to OC which get produced along with EC and can have biogenic as well as secondary sources from the precursor gases (Sun and Arya 2006). The relatively higher OC/EC ratio (7.1) in the north-BoB could be attributed to additional sources of OC other than primary emission source and the formation of secondary organic aerosols during longrange transport (figure 6). The observed ratio in northern $\mathrm{BoB}$ is higher than that estimated from the emission inventories for India and south-Asian countries $(\sim 3.3$; Bond et al 2004). A recent study carried out on carbonaceous species from an urban site in north India by Rengarajan et al (2007), has reported a very high value for OC/EC ratio $(8.47 \pm 2.19)$. Such high ratios have been ascribed to the regional scale biomass burning sources and dominant role of secondary organic carbon. The OC/EC ratios observed in north-BoB therefore, resemble the continental outflow from northern India but ratios (2.5 and 2.6) in south-BoB and north Indian Ocean (NIO) are typically enriched in EC, similar to those reported for urban cities (figure 6).

\subsection{Mineral aerosols ( $\mathrm{Al}, \mathrm{Fe}$ and $\mathrm{Ca}$ )}

The abundance of aluminum (Al) is typically used as an indicator of mineral aerosols of crustal origin (Tindale and Pease 1999; Rastogi and Sarin 2006). However, depending on the lithology of the dust source region, its percentage can vary to a large extent. Moreover, anthropogenic sources may also contribute to atmospheric $\mathrm{Al}$ at certain locations. Thus atmospheric Al abundance at certain sites cannot be simply converted into "mineral aerosols" because it may possibly represent dust as well as anthropogenic fraction containing enriched aluminium. In the following discussion, we have used $\mathrm{Al}$ concentration as an indicator of dust.

In addition, $\mathrm{Fe}$ and $\mathrm{Ca}$ have been also used as a diagnostic tracer for dust. During this study, the average concentrations of $\mathrm{Al}, \mathrm{Fe}$ and $\mathrm{Ca}$ centered around $0.92,0.59,0.73$ and $0.85,0.44,0.90 \mu \mathrm{g} \mathrm{m}^{-3}$ in the Bay of Bengal and Arabian Sea respectively (table 1). A decreasing trend in the abundance of $\mathrm{Al}$ is observable from north to south $\mathrm{BoB}$. AMBT analysis indicates that in northern BoB, air parcels are moving from Indian mainland carrying $\mathrm{Al}$ and $\mathrm{Fe}$ enriched soil dust to the marine region resulting in higher $\mathrm{Al}$ concentration. The spatial distribution of $\mathrm{Al}$ in the $\mathrm{AS}$ shows a conspicuous decreasing trend from southern to northern transect. This decreasing pattern is associated with the changes in wind patterns from north-westerlies (over the southern part) to the south-westerlies prevailing in the northern Arabian Sea. The northwesterly winds transport dust from the coast of Oman; whereas high winds $(9-10 \mathrm{~m} / \mathrm{s})$ prevalent in the northern transect are associated with relatively high abundance of sea-salts. The sources of dust over the Arabian Sea primarily include transport from Oman, Yemen and Rub-Al-Khali sand-sea and, to some extent the sabkha complexes along the south-eastern coast-line of Arabian Peninsula (Pease et al 1998).

One of the important objectives of this study is to characterize the mineral aerosols over the two regions by using crustal element ratios $(\mathrm{Fe} / \mathrm{Al}$ and $\mathrm{Ca} / \mathrm{Al})$. It is assumed that sampling during the spring-intermonsoon season is representative of the dust transport to the MABL from 

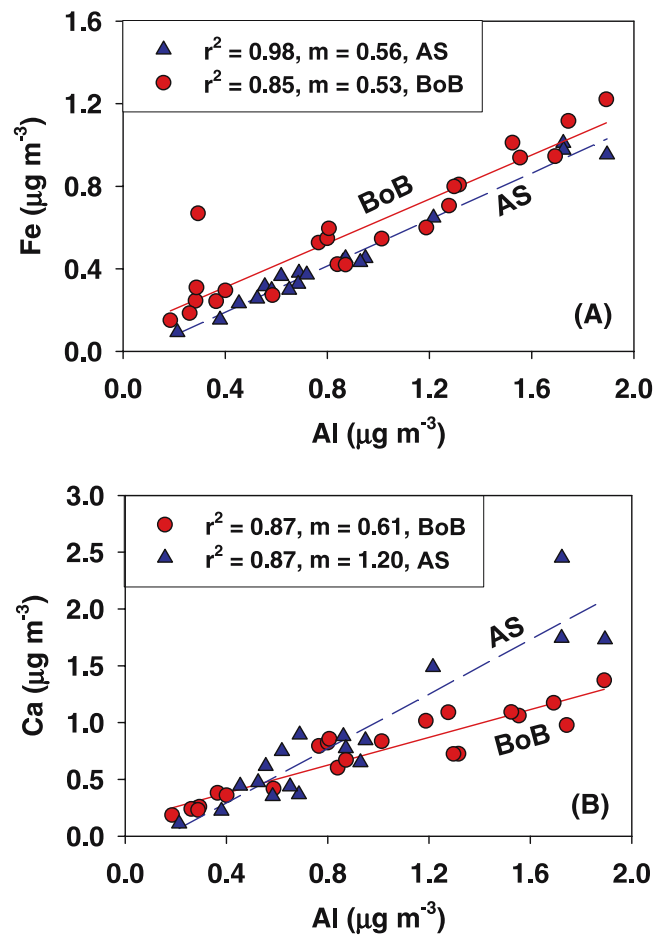

Figure 7. Scatter plot of $\mathrm{Al}$ with crustal components (Fe and $\mathrm{Ca}$ ) exhibit characteristically different slopes for Ca vs. $\mathrm{Al}$ but remarkably similar for $\mathrm{Fe} v s$. Al.

the regional source regions. The linear regression analysis performed among these elements, considering $\mathrm{Al}$ as index of dust, yields significant regression coefficients: $\mathrm{Fe}\left(r^{2}=0.85\right.$ and 0.98$)$, and $\mathrm{Ca}\left(r^{2}=0.87\right.$ and 0.87$)$ for $\mathrm{BoB}$ and $\mathrm{AS}$ respectively, suggesting their cogenetic source and/or no fractionation during transport to the MABL (figure 7). The average $\mathrm{Fe} / \mathrm{Al}$ ratio observed over $\mathrm{BoB}$ and $\mathrm{AS}$ is $0.72 \pm 0.37$ and $0.51 \pm 0.05$, relatively higher than $\mathrm{Fe} / \mathrm{Al}$ ratio in upper continental crust (0.44; Taylor and McLennan 1985). On the other hand $\mathrm{Ca} / \mathrm{Al}$ ratio, $0.81 \pm 0.16$ and $0.89 \pm$ 0.27 , a factor of $2-3$ higher than that expected from UCC (0.38; Taylor and McLennan 1985) indicates that dust is rich in calcium carbonate with a high capacity to neutralize acidic species. The neutralization of acidic species (sulphate) by dust is revealed from linear regression observed among nss- $\mathrm{SO}_{4}^{2-}$ and nss-Ca ${ }^{2+}$ (figure 4); with molar ratio of $\mathrm{nss}-\mathrm{Ca}^{2+} / \mathrm{nss}^{-} \mathrm{SO}_{4}^{2-}$ ranging from 0.12 to 0.50 $(\mathrm{Av}=0.28)$ and 0.20 to $1.16(\mathrm{Av}=0.61)$; attesting to the fact that nss- $\mathrm{SO}_{4}^{2-}$ dominates in $\mathrm{BoB}$ whereas $\mathrm{Ca}^{2+}$ dominates in the AS.

\section{Conclusions}

The chemical characteristics of bulk-aerosols from the MABL of Bay of Bengal and Arabian Sea, studied during the spring and inter-monsoon seasons, reveal comparable abundance of TSP over the two oceanic regions. However, the relative dominance of non-sea-salt sulphate and $\mathrm{NH}_{4}^{+}$in the water-soluble ion composition of bulk-aerosols over BoB, in contrast to Arabian Sea, arises from advective transport of continental pollutants to the Bay region. This is further reflected in the higher abundance of $\mathrm{OC}$ and $\mathrm{EC}$ over BoB. The near quantitative $\mathrm{Cl}^{-}$-depletion from sea-salts by chemical interaction with anthropogenic sulphate provides added evidence to the processing of acidic species within the MABL. This has implication to the role of sea-salts as a dominant sink for sulphur dioxide. The relatively higher mass fraction of mineral dust over southern Arabian Sea than over north-Arabian Sea is a notable feature of this study. This feature indicates that the composition of air sampled in the northern section is quite different from the airmass transported to the south Arabian Sea.

\section{Acknowledgements}

This study was supported by ISRO-GBP, as a part of the Indian national programme on Integrated Campaign on Aerosols Trace Gases and Radiation Budget (ICARB). We wish to thank Dr. K Krishna Moorthy (Chief-Scientist) for efficient organization of the campaign. We are grateful to Dr. S K Satheesh for providing high-volume sampler for sampling during the two legs. We would also like to acknowledge efforts made by Mr. L A K Reddy and Dr. U C Kulshrestha for help with the collection of aerosol samples in the Bay of Bengal. It is pertinent here to thank the ship's captain and his crew members for providing all the help onboard Sagar Kanya.

\section{References}

Arimoto R 2001 Eolian dust and Climate: Relationship to sources, tropospheric chemistry, transport and deposition; Earth Science Rev. 54 29-42.

Birch M E and Cary R A 1996 Elemental carbonbased method for monitoring occupational exposures to particulate diesel exhaust; Aerosol Sci. Technol. 25 221-241.

Bond T C, Streets D G, Yarber K F, Nelson S M, Woo J and Klimont Z 2004 A technology-based global inventory of black and organic carbon emissions from combustion; J. Geophys. Res. 109 D14203, doi: 10.1029/ 2003JD003697.

Charlson R J, Schwartz S E, Hales J M, Cess R D, Coakley J A, Hansen J E and Hoffmann D J 1992 Climate forcing by anthropogenic aerosols; Science 255 423-430.

Duan F et al 2005 Characteristics of carbonaceous aerosols in Beijing, China; Chemosphere 60 355-364. 
Duce R A and Tindale N W 1991 Atmospheric transport of iron and its deposition in the Ocean; Limn. Ocean 36 $1715-1726$.

Jickells T D et al 2005 Global Iron Connections Between Desert Dust, Ocean Biogeochemistry, and Climate; Science 308 67-71, doi: 10.1126/science.1105959.

Kumar A, Sarin M M and Sudheer A K 2008 Mineral and Anthropogenic Aerosols in Arabian Sea-Atmospheric Boundary Layer during Inter-monsoon: Sources and Spatial Variability; Atmos. Env. 42 5169-5181, doi: 10.1016/j.atmosenv.2008.03.004.

Kulshrestha U C, Saxena A, Kumar N, Kumari K M and Srivastava S S 1998 Chemical composition and association of size differentiated aerosols at a suburban site in a semi-arid tract of India; Journal of Atmospheric Chemistry 29 109-118.

Kerminen V M, Teinila K, Hillamo R and Pakkanen T 1998 Substitution of chloride in sea-salt particles by inorganic and organic anions; J. Aerosol Sci. 29(8) 929-942.

Martin J M et al 1989 River versus atmospheric input of material to the Mediterranean Sea: An overview; Mar. Chem. 28 159-182.

Momin G A, Rao P S P, Safai P D, Ali K, Naik M S and Pillai A G 1999 Atmospheric aerosol characteristics studies at Pune and Thiruvananthapuram during INDOEX programme-1998; Curr. Sci. $\mathbf{7 6}$ 985-989.

Mayol-Bracero O L et al 2002 Carbonaceous aerosols over Indian Ocean during the Indian Ocean Experiment (INDOEX): Chemical characterization, optical properties, and probable sources; J. Geophys. Res. 107(D19) 8030, doi:10.1029/2000JD000039.

Norman M, Leck C and Rodhe H 2003 Differences across the ITCZ in the chemical characteristics of the Indian Ocean MBL aerosols during INDOEX; Atmos. Chem. Phys. 3 563-579.

Pease P P, Tchakerian V P and Tindale N W 1998 Aerosols over the Arabian Sea: geochemistry and source areas for Aeolian desert dust; J. Arid Environment 39 477-496.

Prospero J M, Glaccum R A and Nees R T 1981 Atmospheric transport from Africa to South America; Nature 289 570-572.

Quinn P K et al 2004 Aerosol optical properties measured on board the Ranald H. Brown during ACE-Asia as a function of aerosol chemical composition and source region; J. Geophys. Res. 109 D19S01, doi: 10.1029/ 2003JD004010.

Ramanathan V, Crutzen P J, Kiehl J T and Rosenfeld D 2001a Aerosols, climate and the hydrological cycle; Science 294 2119-2124.
Ramanathan V et al 2001b Indian Ocean Experiment: An integrated analysis of climate forcing and effects of the great Indo-Asian haze; J. Geophys. Res. 106 $28,371-28,398$.

Rastogi N and Sarin M M 2005 Long-term characterization of ionic species in aerosols from urban and high-altitude sites in western India: Role of mineral dust and anthropogenic sources; Atmos. Environ. 39 5541-5554.

Rastogi N and Sarin M M 2006 Chemistry of aerosols over a semi-arid region: Evidence for acid neutralization by mineral dust; Geophys. Res. Lett. 33 L23815, doi: 10.1029/2006GL027708.

Rengarajan R, Sarin M M and Sudheer A K 2007 Carbonaceous and inorganic species in atmospheric aerosols during wintertime over urban and high-altitude sites in North India; J. Geophys. Res. 112 D21307, doi:10.1029/2006JD008150.

Sarin M M, Rengarajan R and Krishnaswami S 1999 Aerosol $\mathrm{NO}_{3}-$ and $210 \mathrm{~Pb}$ distribution over the central eastern Arabian Sea and their air-sea deposition fluxes; Tellus 51B 749-758.

Smith D J T et al 1996 Concentration of particulate airborne polycyclic aromatic hydrocarbons and metals collected in Lahore, Pakistan; Atmos. Environ. 30 4031-4040.

Sun J and Ariya P J 2006, Atmospheric organic and bioaerosols as cloud condensation nuclei $(\mathrm{CCN})$ : A review; Atmos. Environ. 40 795-820.

Taylor S R and Mclennan S M 1985 The Continental Crust: its composition and evolution (Oxford: Blackwell) pp. 312.

Tindale N W and Pease P P 1999 Aerosols over the Arabian Sea: atmospheric transport pathways and concentrations of dust and sea-salt; Deep-Sea Res. II 46 1577-1595.

Turpin B J and Lim H 2001 Species contribution to PM2.5 concentrations: Revisiting common assumptions for estimating organic mass; Aerosol. Sci. Technol. 35 $602-610$.

Twomey S 1997 Atmospheric Aerosols (New York: Elsevier Sci.) $302 \mathrm{pp}$

Venkataraman C, Reddy C K, Josson S and Reddy M S 2002 Aerosol size and chemical characteristics at Mumbai, India, during the INDOEX-IFP (1999); Atmos. Environ. 36 1979-1991.

Witz S, Eden R W, Wadley M W, Dunwoody C, Papa R P and Torre K J 1990 Rapid Loss of Particulate Nitrate, Chloride and Ammonium on Quartz Fiber Filters during Storage; Journal of the Air \& Waste Management Association 40(1) 53-61.

Wu P M and Okada K 1994 Nature of coarse nitrate particles in the atmosphere - a single particle approach; Atmos. Environ. 28 2053-2060. 